\title{
Screendance Narratives from around the Mediterranean Sea
}

\author{
Ariadne Mikou \\ in collaboration with Elisa Frasson \\ and with the contribution of Anna Alexandre, Marisa Hayes \& Franck Boulègue, \\ Chrysanthi Badeka, Lucia De Rienzo, Simona Lisi, Marco Longo and Loránd János
}

\begin{abstract}
The European Mediterranean appears to be an active key player for the production and circulation of screendance. Focusing this research on the pre-pandemic state of screendance in Italy, France, Greece and Spain and employing a methodology of oneto-one interviews, this text examines the art policies that have been in place for potentially supporting the production of screendance, the ways that spectatorship and social engagement kept on growing and the predictions for the yet-to-come evolution of the form in a context disassociated from, yet applicable to the on-going pandemic. Although screendance is understood differently among the interviewees - curators of major festivals such as DAN. CIN. LAB., Festival International De Vidéo Danse De Bourgogne, COORPI/La Danza in 1 minuto, Cinematica Festival, Stories We Dance International Videodance Contest, Choreoscope - The International Dance Film Festival of Barcelona and the formerly known Athens Video Dance Project - International Dance Film Festival - the aim of this research is to create knowledge regarding the heterogeneous landscape of screendance in the European Mediterranean as well as a broader understanding of the shifting Mediterranean culture.
\end{abstract}

Keywords: screendance, economies, spectatorship, social engagement, interviews, European Mediterranean

\section{Introduction}

This text is the outcome of a series of interviews that were addressed to key figures in screendance curation active in the European part of the Mediterranean area - excluding the former European colonies in this geographical zone. These interviews, conducted right before the outbreak of COVID-19, examine different modes and restrictions on screendance production in the Mediterranean area, strategies of dissemination and social engagement emerging from the artform, narratives of local legacies and future perspectives on the form.

The International Journal of Screendance 11 (2020). https://doi.org/10.18061/ijsd.v11ii0.7968

(c) 2020 Mikou. This article is published under a Creative Commons Attribution 4.0 International License (https://creativecommons.org/licenses/by/4.0/) 
The intention of this project shares the editorial agenda to decentralise - and expand (authors' emphasis) - the academic discourse on screendance beyond the Englishspeaking scholar context of IJSD which is mainly circulated in the USA, Canada and the UK. Our goal is to offer perspectives and insights from the European Mediterranean, a geographical and socio-economical area currently active in screendance production and dissemination.

As artists, curators and writers originating from and recently being relocated in the European part of the Mediterranean, our curatorial and teaching projects mainly take place in Italy, a Mediterranean country by definition. Our focus is, on one hand, to contribute to the expanded understanding of the notion of screendance in academic and artistic contexts, ${ }^{1}$ and on the other hand to make this interdisciplinary art form available and appreciated by a larger and non-expert audience. At the same time, we are interested in exploring how screendance may turn into a tool for building social awareness. $^{2}$

At this particular stage of the research, the Mediterranean countries of focus are Italy, France, Greece and Spain and it is important to remind the reader of the pre-COVID 19 sociopolitical landscapes in relation to cultural policy in each one of these countries. France has a long tradition of providing support to the Arts while Italy, Spain and Greece have been influenced in different ways by the 2008 financial crisis. Greece has been especially affected by the austerity measures that followed and almost diminished any kind of state support towards the Arts approximately until 2018. In addition, Spain, Italy and in particular Greece have been hit by the large and uncontrolled migrant crisis that is the outcome of the massive displacement of people fleeing war in areas such as Africa and the Middle East. Keeping in mind this frame, by looking at the pre-COVID 19 state of screendance - a form that primarily engages the human body, and by extension motion, as well as the screen, a surface that is an integral part of everyday communication - how can we help others understand the particularities of the place where we live? How can we enhance our own understanding of the socio-cultural area where we currently reside?

Regarding the structure and technical aspects of the interviews, we conducted and registered them via Skype in December 2019 - around three months before the official lockdown in Europe (a fact that perhaps gives a historic dimension to the project given that it is unclear how long the measures of social distancing will last, and how they will affect the evolution of the Arts). The interviews were strategically structured as discussions ${ }^{3}$ and they were with:

- Anna Alexandre from DAN. CIN. LAB. (Saint-Etienne, France)

- Marisa Hayes \& Franck Boulègue from the Festival International De Vidéo Danse De Bourgogne (Le Creusot, France) 
- Chrysanthi Badeka from the Athens Video Dance Project - International Dance Film Festival(Athens, Greece) ${ }^{4}$

- Lucia De Rienzo from COORDINAMENTO DANZA PIEMONTE (COORPI)/La Danza in 1 minuto (Torino, Italy)

- Simona Lisi from Cinematica Festival - Immagine in Movimento: Performance, Arti Visive, Cinema, Nuove Tecnologie (Ancona, Italy)

- Marco Longo from collettivo Augenblick / Stories We Dance International Videodance Contest of Fuori Formato - Festival Internazionale di Danza e Video Danza (Genova, Italy)

- Loránd János from Choreoscope - The International Dance Film Festival of Barcelona (Spain)

We invited responses from these curators, as residents in the European part of the Mediterranean area, who are engaged in different ways in the development of the field of screendance. Most have been working since around 2010. As they direct major screendance festivals and most of them are connected through specific network schemes and alliances - for instance, The Mediterranean Screendance Network (MSN) ${ }^{5}$ and the Creative Europe funded project $\mathrm{mAPs}^{6}$ - they are an integral part of screendance in the Mediterranean region.

The project is driven by the authors as artists-researchers and curators working independently from institutions and this factor does shape the research process and necessarily the outcome. ${ }^{7}$ In future iterations of the project, we aim to develop further collaborations both within and beyond the European zone of the Mediterranean area and we also plan to invite academic voices to comment and broaden the scope of the work. At this stage, it has been useful in the research to employ a mapping process that aims to locate the centres of screendance dissemination in the area of focus such as independent festivals that are currently operating although their activities might have been suspended due to the measures against the spread of COVID-19. For the purposes of this paper, only a small selection of dance, film and video art festivals with special programs on the body on the screen are included. 


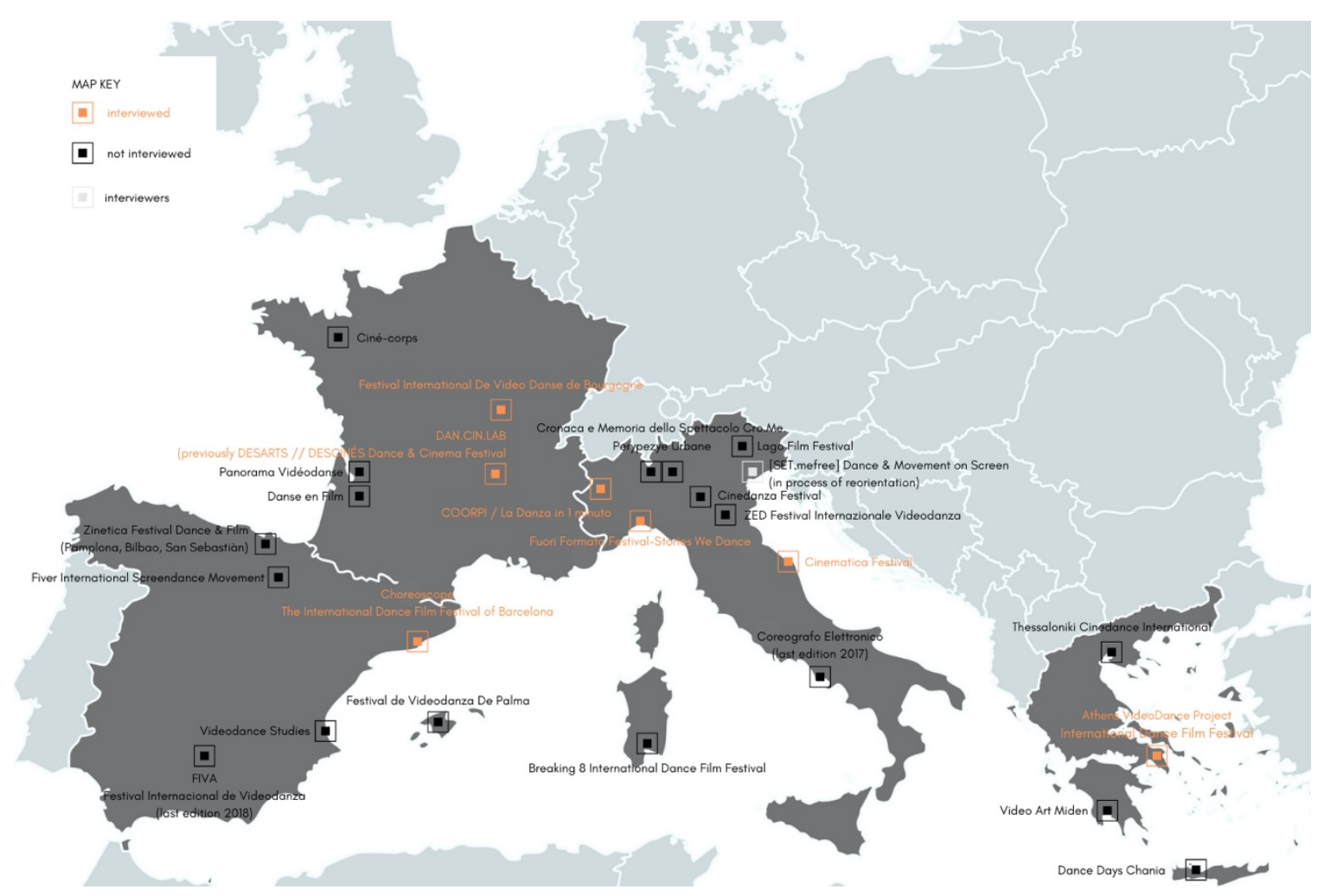

Location of independent festivals and organisations that are currently operating in Italy, France, Greece and Spain. Map: Ariadne Mikou

Our interviewing method allowed us to refine questions and respond to the research as it emerged. Questions below appear in the order that they were addressed in each interview and the responses are presented as edited summaries underneath each question. The first question asked each interviewee for a general overview of screendance production in each country. A geographical clockwise movement that begins with Italy and ends with Spain determines the sequence of answers. The rest of the questions - except from the last one that appears as a summary - are answered personally and the participants are identified by their names and affiliation. This order follows the sequence assigned above.

The interviews took place in the language native to the interviewees - Italian and Greek - and then they were translated into English. In some cases, they were also conducted in English, which for the authors of this paper and most of the participants is a second language. The translation process necessarily drew attention to questions of language; one of our key findings is that the term 'screendance' is rarely used in the geographical zone of this research. As writers, whenever possible, we use the term 'screendance' while "keeping in mind the slippery definitions of dance, choreography, screen and their expanding and transgressed borders." ${ }^{8}$ However, in the cases of Augenblick Colletivo, COORPI, DAN.CIN.LAB. and Choreoscope all use the term 'dancefilm'. ${ }^{9}$ The Festival 
International De Vidéo Danse De Bourgogne aims for a more holistic approach towards definitions of what might constitute screendance and Cinematica Festival is oriented towards a broader understanding of screendance as Movement Image (Deleuze, 1983). The contradictory title of Athens Video Dance Project - International Dance Film Festival (AVDP) makes available the medium of video as part of a filmic environment and AVDP seems to be a promoter of works that embraces video and film alike.

\section{Question One}

1. How is the production of screendance enabled in your country? Which are the available financial resources that circulate? ${ }^{10}$

Referring specifically to Italy and France, the interviewees agree that screendance flourished under the form of 'videodance' ${ }^{11}$ during the $80 \mathrm{~s}$ and $90 \mathrm{~s}$. Then there was a gap of approximately 10 years and around 2010 the form reappeared under the name 'dancefilm.' The French and Italian interviewees concur that the audio-visual form that unites dance and choreography with the screen is going through a second big wave or golden age (orig. emphasis) in terms of production and circulation.

ITALY

The three interviewees from Italy (Lucia De Rienzo, Simona Lisi \& Marco Longo) agree that there is a lack of financial opportunities specifically for hybrid forms such as screendance or videodance. However, they acknowledge the availability of financial resources for cinema and dance as discrete art forms. In the case of dance, these funding schemes are predicated towards the distribution of dance rather than the production of new work. All of the interviewees make explicit that artists might sometimes re-invent their projects for a specific community or as part of an educational program in order to make it fit to the given financial frames that are separately available for cinema and dance. Additionally, artists and producers might need to adjust their language when applying for grants. More specifically, when requesting financial support for audio-visual projects from the dance sector, it can be helpful to rephrase the artistic outcome not as a videodance per se but as a mediated dance performance for the screen. These small (authors' emphasis) language adjustments can help to transcend the borders of the two artforms in the eyes of funders.

Artists and producers find their way in Italy through the available options below:

1. FONDO UNICO PER LO SPETTACOLO (FUS) which is a ministerial funding resource for the Performing Arts in Italy. More specifically, article 41 of FUS states that funding is available for the promotion of the performing arts. For example, the use of the word 'video' in a funding application from a screen artist can open the door for the creation of trailers for dance performances and/or adaptations for these on screen that might be developed into original videodance works. 
2. PER CHI CREA ${ }^{12}$ which is a project co-funded by SIAE ${ }^{13}$ and the Italian Ministry of Culture. It is dedicated only to youth creativity (up to 35 years old).

3. Funds from the local municipalities and regions that aim to support live performances or cinema.

4. Bank Foundations and other private institutions. ${ }^{14}$

5. Opportunities for artists residencies that may produce as outcomes works created for the screen. ${ }^{15}$

6. The creation of networks that facilitate co-productions. In this sense, as Longo suggests, the artistic process develops a dimension often based on contacts and cross-institutional support.

7. Resources from abroad, as for instance the production of Carte Blanche ${ }^{16}$ by the Italian collective Augenblick. It received support from Stavros Niarchos Foundation in Greece as part of the cultural activities of the LIRCES Conference on Greek-born Italian poet Ugo Foscolo.

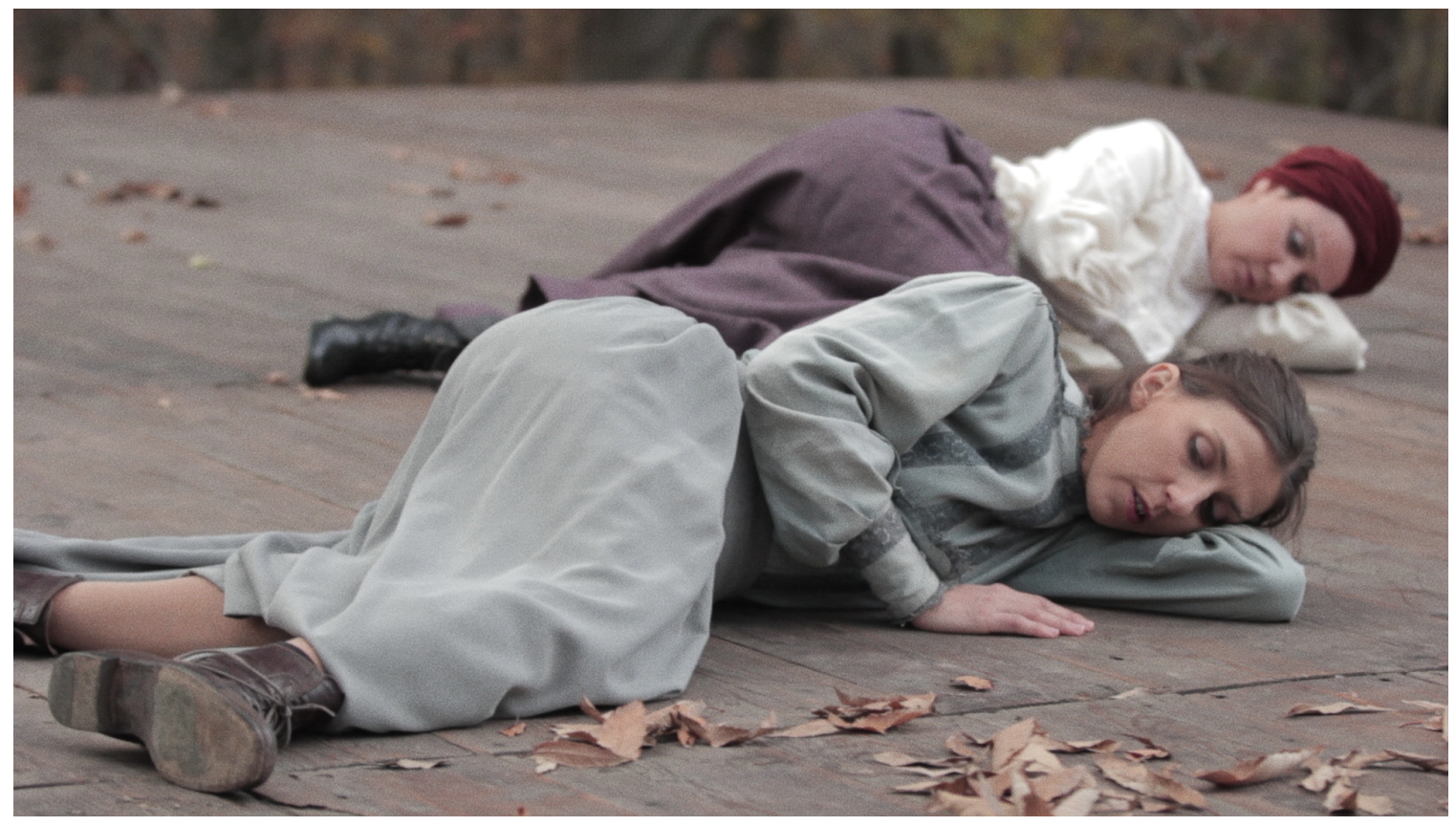

Still from Carte Blanche. Direction and choreography Collettivo Augenblick, 2017. Film.

\section{FRANCE}

According to Anne Alexandre from DAN.CIN.LAB. as well as Marisa Hayes \& Franck Boulègue, the directors of Festival International De Vidéo Danse De Bourgogne, financial resources available in France include:

1. The National Film Funding that is accessed through a single production company as well as a recognised production company with a track record but not by individual artists. An additional difficulty for the dance filmmakers, according to Alexandre, is that the majority of the film resources do not 
recognise dancefilm as a film genre. Also, screendance (danse pour /'écran in French) is a term that is not appreciated by the film industry and to indicate quality and high standard artists and producers need not to differentiate dancefilm, dance cinema or ciné-dance from film.

2. A scheme developed two years ago by the Dance Division of the Ministry of Culture which opened an experimental Call on Dance Film in dialogue with the National Film Funding. Hayes reports that currently "a certain amount of grants for choreographic creation are available to fund audio-visual projects in relationship to dance (screendance, documentaries, and others)." 17

3. Canal Plus, a prepaid TV channel as well as a production company, offers a residency program with the support of the Centre National du Cinéma et de I'Image Animée. The 2020 edition was inaugurated with the production of $L a$ collection: Comédie Musicale, a collection of seven short musical films in which dance was an integral part.

4. A screendance residency initiated by Festival International De Vidéo Danse De Bourgogne in collaboration with La Briqueterie CDCN du Val-de-Marne and a large group of partners mainly coming from France. It includes a two-week residency and financial support up to 8,000 euros for production and artistic creation. ${ }^{18}$

5. There are funding opportunities for collaborative projects with Arabic countries (Lebanon, Syria) and former French colonies (Morocco, Tunisia).

6. The Anna Lindh Foundation promotes projects in the Mediterranean area for peace and equality across countries. ${ }^{19}$

7. French Institutes abroad may provide funding for dancefilm productions. ${ }^{20}$

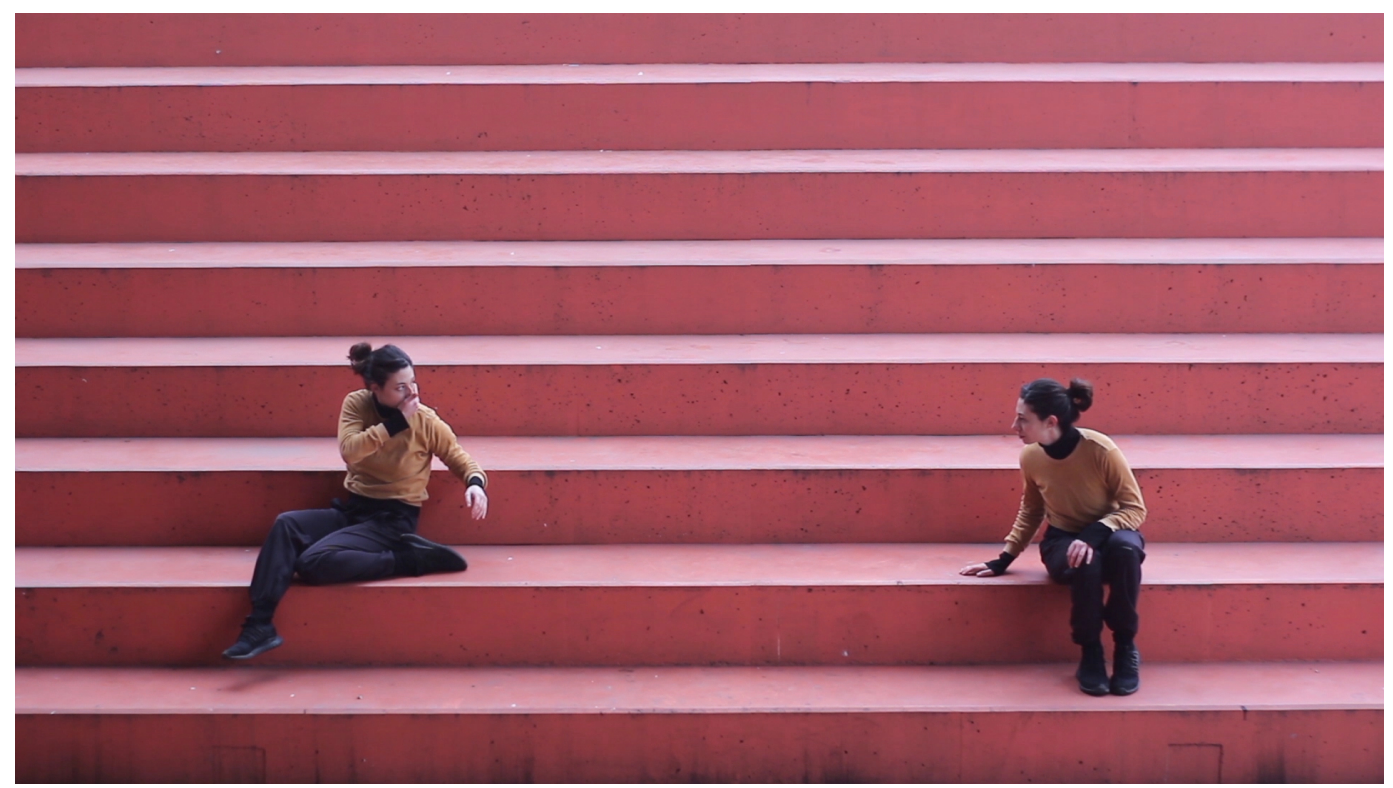

Still from Aporia, the project that was co-funded by Festival International De Vidéo Danse De Bourgogne. Direction and choreography Salvatore Insana and Elisa Turco Liveri, 2019. Screendance. 
GREECE

"AVDP (Athens Video Dance Project-International Dance Film Festival) was born during the years of the financial crisis." 21

Despite the impoverishment of the country during the last decade caused by the financial crisis and the austerity measures, artists by engaging minimal tools managed to have a strong presence abroad. According to Chrysanthi Badeka, the former codirector of AVDP, artists were able to produce works that communicated an engaging story and conveyed directly a message. Collaboratively, Greek artists have recently been proposing works that leave a strong imprint in the screendance market ${ }^{22}$ or works with a rich socio-political context ${ }^{23}$. However, a contrast between available resources and the creation of artworks might be described as both miraculous and audacious: artists create almost with no financial support and the lack of resources pushes them to be even more creative. Although financial opportunities still remain few, an increase in accessibility to technologies continues to affect artistic production and dissemination positively.

SPAIN

Loránd János, the director of Choreoscope - The International Dance Film Festival of Barcelona, in answer to the question about the availability of financial resources that circulate in Spain says explicitly: "NONE." There is no funding for screendance and this is the reason, he explains, why the Mediterranean Screendance Network (MSN) was created. He continues: "to create a sort of lobby in order to gain joint visibility, to develop work together and access financial resources as a strong team." The MSN has been operating for three years and it is still mainly European as it includes festivals from France, Greece, Italy and Spain. As János adds "we continue to seek exchanges with other European Mediterranean countries (e.g. Malta, Cyprus)."

\section{Question Two}

2. Through which ways does spectatorship grow within and beyond the context of your 'videodance' or 'dancefilm' festival?

De Rienzo from LA DANZA IN 1 MINUTO CONTEST: We developed a digital audience and followers through social media (Facebook and Instagram), the video platform Vimeo and our own website. In 2019, in order to reach the new generation, we launched a new category dedicated to 1-minute works shot with a smartphone. This digital audience still prefers the ease of home viewing through cell phones, computers, iPads and resists visiting physical spaces, such as cinemas or museums in order to engage further with other forms of screendance.

Lisi from CINEMATICA Festival. With curatorial formats such as special screenings ${ }^{24}$, exhibitions, installations, multimedia and site-specific performances, we aim to address 
our work to a large audience originating from the visual and performing arts as well as the field of cinema. Curating workshops with experienced artists for professionals and amateurs of every age, holding academic conferences, hosting meetings with film directors (e.g. Peter Greenaway) and choreographers, as well as the creation of Jirí Kylián's Scalamare, ${ }^{25}$ that was co-produced by our festival, helped to further augment spectatorship.

Specifically speaking about Scalamare, it was shot in one of the landmarks of Ancona, the Monumento ai Caduti, which is a tourist attraction and a haunt that gathers many people daily. Shoots on location built the curiosity of the residents, who visited the site day after day to observe the process of the filming or to attempt to meet the cast. When the film was ready for distribution, we invited the residents to attend the premiere and they responded eagerly to our invitation. We have to consider that videodance was unknown at that point to the local citizens and creating a work that presents their city on the screen, was very important for them. By extension, this action helped to build a sense of pride in their hometown. As Scalamare toured in several major festivals around the world, our festival's reputation increased.

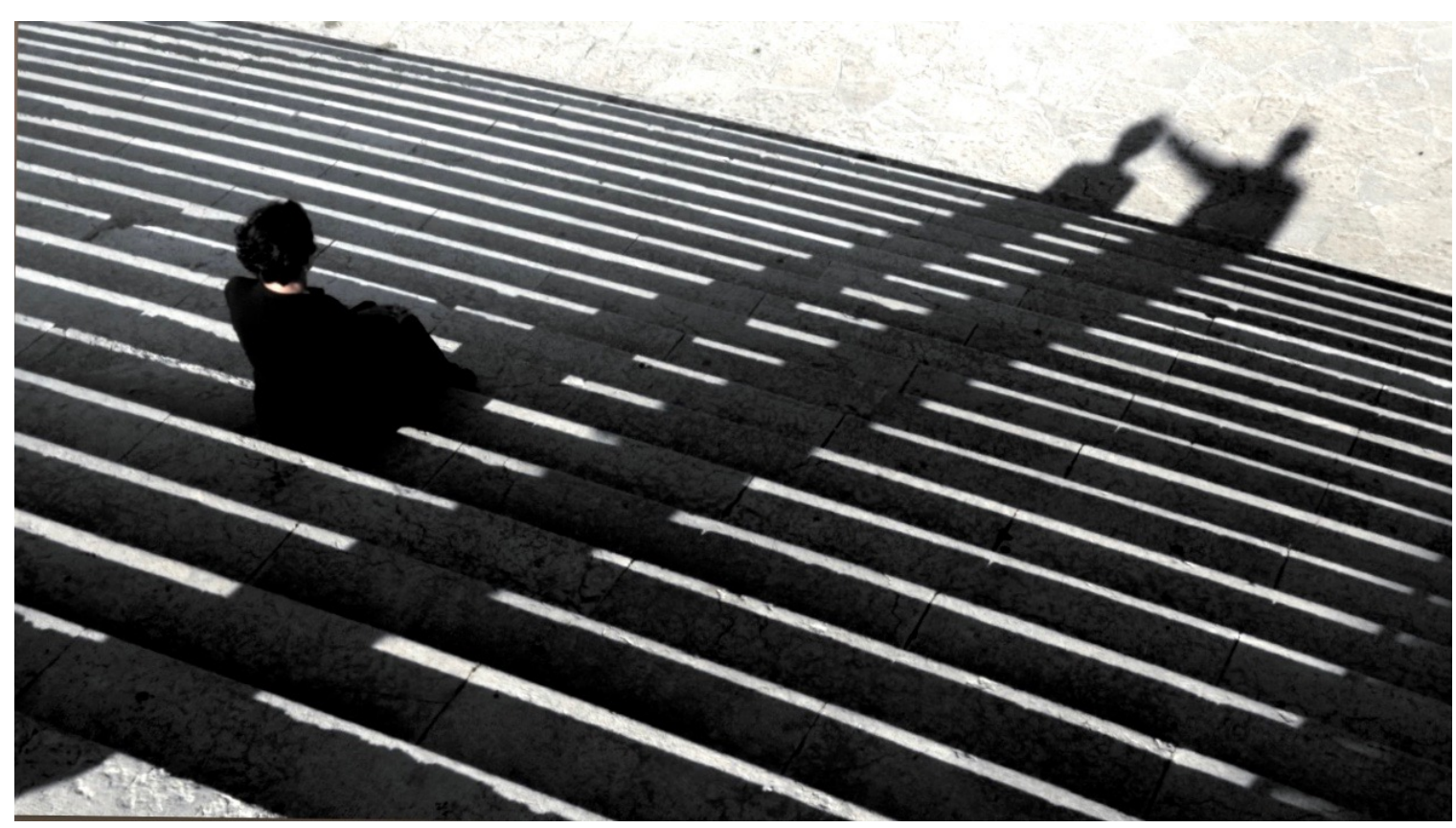

Scalamare, 2014. Dir. and chor. Jirí Kylián. Prod. Kylián Foundation, Cinematica Festival, Comune di Ancona, Marche Teatro. Film.

Longo from COLLETTIVO AUGENBLICK (Stories We Dance International Videodance Contest): For growing the audience for our curatorial activities, we engage an interdisciplinary dialogue with other arts. We attempt to go out from our own cinematic and performative sphere in order to develop meeting points with other contexts and to 'contaminate' ${ }^{26}$ screendance as well as the choreographic discourse through diverse 
approaches. We organise practical workshops and lectures with screenings, as for instance, our event which is called Videodance and the Other Art Forms that aims to connect videodance with cinema, theatre and architecture. This is a way to attract an audience from other disciplines beyond the fields of dance and cinema.

Alexandre from DAN.CIN.LAB.: In our first steps as curators and in order to introduce dancefilm in the area of Saint-Etienne, our strategy was to approach screendance through screenings on the popular heritage of dance on film (West Side Story, Pulp Fiction; Blues Brothers etc). Then, as our project began to orient towards social issues, long form films from the cinema industry were accompanied by a program of short dancefilms connected to the featured cinema director or the topic of the main film. Currently, our events are followed by after-screening talks with experts on the field, such as filmmakers, choreographers or dancers. We also organise a lot of screenings of short dancefilms outdoors because the audience does not go to the cinema to attend shorts. They prefer feature films. So, DAN.CIN.LAB. started to place the screen outdoors in the urban space such as the streets, the parks, the museums ${ }^{27}$, at the shops and on the squares. This idea was successful because people remained to watch the films.

Hayes and Boulègue from Festival International De Vidéo Danse De Bourgogne: In France, most of the financial resources are gathered and centralised in large cities and especially in Paris. But, in Le Creusot ${ }^{28}$, a small city in the region of Burgundy and the home of our festival, there was far less competition for initiating a project such as a screendance festival.

In our festival, we aim at being 'glocal' (global and local at the same time) and we question how to create a dialogue between the local residents and the international public. In the early editions of the festival -- around 11 years ago -- we used to curate programs that provided an overview of different screendance practices. These programs gradually moved towards thematic festivals. Speakers from France and abroad were invited to give lectures as part of international screendance conferences organized in relationship to festival themes, including The Politics of Space (2015) and the economy and ecology of Low-Tech/Old Tech (2017). Encouraging artists to visit Le Creusot, make films and attend workshops on location, helped the residents to discover the festival and gradually built their curiosity. We have also been proposing collective works of screendance since 2013 through an "exquisite corpse technique." ${ }^{29}$ Free entry for the public and no-fee submission for the artists were other strategies adopted. For the last three years, we have received enough funding to pay the artists for their films. 


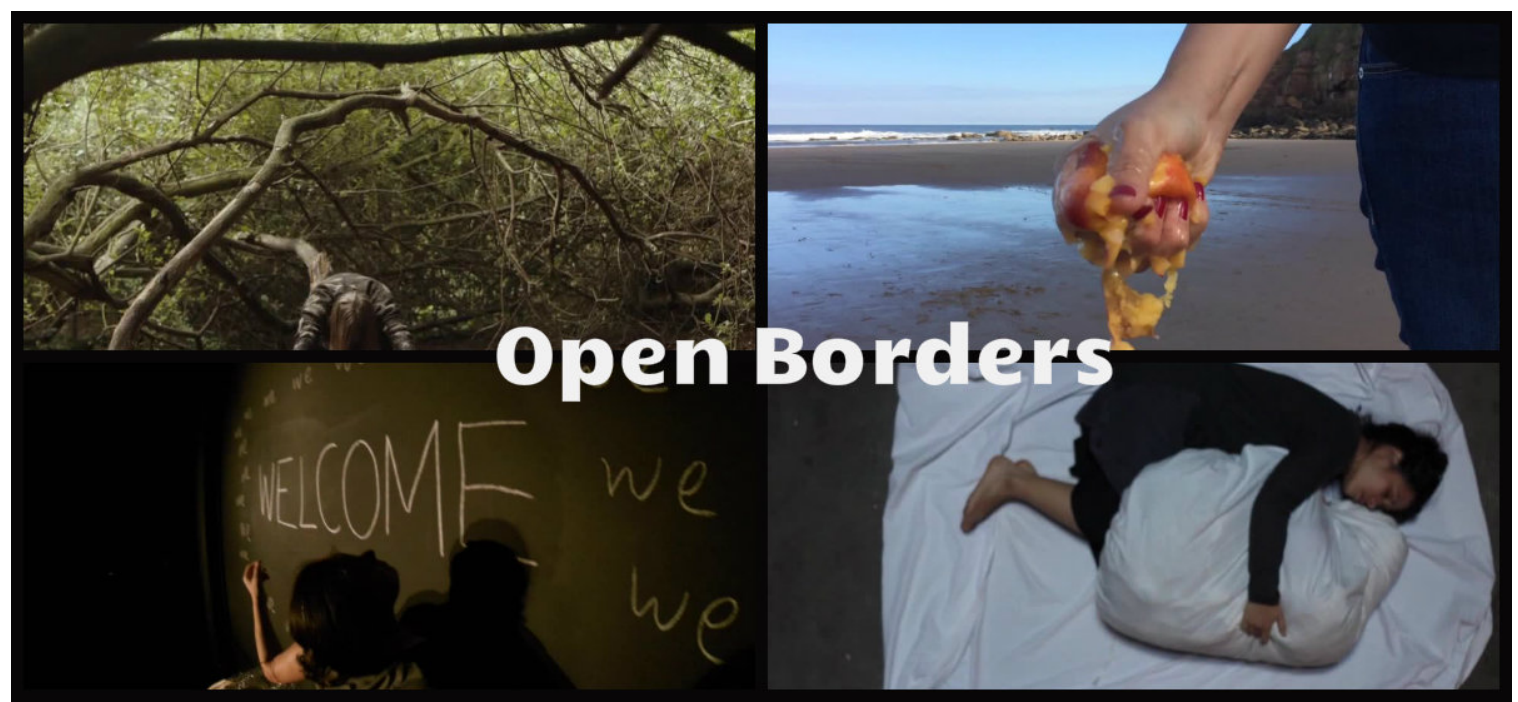

Still from Open Borders, 2015.

Badeka from AVDP (Athens Video Dance Project-International Dance Film Festival): AVDP was created in order to show our works. As artists-curators we were interested in treating the featured artists with care and respect. We wanted them to be happy and we treated them as we wanted ourselves to be treated. This ethos of care was recognised by our followers through time and increased the audience which initially consisted of local artists. This kind of care is not measured in terms of financial profit but rather as an attitude that promotes visibility for the artists in international festivals and platforms. Ethos of care and respect for the participating artists also builds their trust towards the curators.

Furthermore, we aimed to support Greek artists, although, in the beginning, their works were at an early stage of technical and artistic development. We think that their selection at our festival was a reward and motivation for them as we hope that AVDP became an opportunity to deepen understanding of the form as it evolved in Greece and internationally.

Our additional dissemination tactics for audience development include several educational projects as well as the project $A V D P$ on TouR in which we promote a national circulation of screendance programs as part of several Greek Dance Festivals with whom we collaborate permanently or occasionally ${ }^{30}$.

János from CHOREOSCOPE-The International Dance Film Festival of Barcelona: Besides the use of social media for communication, the Filmin platform ${ }^{31}$ helps the visibility of the form. The Choreoscope short film catalogue is made available on Filmin after the festival ends around the middle of October and it is available to be streamed until December 31st. This is an agreement that we as Choreoscope reached with this platform in order to promote further the artists, their dancefilms and assure a broader audience for their work. At the same time the viewings generate income for the artists. 
Furthermore, having a clear identity as a festival is important for expanding our audience. We need to know what we are talking about in order to be able to sell it and to explain it to our audience. We have a clear branding strategy to communicate to the audience what they can expect to see at our festival. Choreoscope is a FILM FESTIVAL (orig. emphasis), focused on dance, choreographed movement and non-verbal communication. We screen films (shorts, animation, feature, documentary and series) where the stories are told by the body, or the dance/movement element has a clear narrative and dramaturgic weight.

\section{Question Three}

\section{What is the potential of the form for social engagement and how is it practised especially by your organisation?}

De Rienzo from LA DANZA IN 1 MINUTO CONTEST: There is an urgency in the Mediterranean area, especially after the financial and migration crisis that changed our society, to begin to speak about social issues. So, the crisis changed the content of the works and rendered them more urgent and perhaps less aesthetic. These works have the possibility to speak to a broader audience and help it to connect with them.

Lisi from CINEMATICA Festival. I believe that we should be involved in collaboration projects around the Mediterranean area not only for circulating works among festivals but as well as for producing collective films internationally. A lot of questions can be raised through the common language of the body, so I think that in the future it will be possible to use videodance (the body on the screen) for sharing and conveying ideas around social themes.

Longo from COLLETTIVO AUGENBLICK (Stories We Dance International Videodance Contest): There is a central question for us as a collective regarding creating and curating art in the Mediterranean area: "What makes you move? (authors' trans.)" 32 where you (authors' emphasis) refers to the spectator, the dance-artist, the choreographer and the cinematographer as well as the curator. This question aims to stimulate motion at a physical as well as at a socio-political level and to expand the choreographic discourse.

Alexandre from DAN.CIN.LAB.: Dancefilm is a tool to understand how we can make society together. Our first concern is to produce and disseminate (dance)films addressing social issues. To connect reality with technology. DAN.CIN.LAB. has been producing short dance films and documentaries since 2015 involving in various inclusive ways local populations (as for instance youth, adults, people with disabilities, migrants) in front or behind the camera. 
We all share a body that is political and this is a strong vehicle to support and translate emotions, sensations and to convey thoughts and questions. Moving body mixed with cinema, image speaking broadly, becomes even a stronger tool to talk to people and make people talk together. In DAN.CIN.LAB., we have screened programs on dance \& equality, migration, mutation in the city space, civil rights, differences and prejudice (LGBT+). To summarise, we work towards expanding the art form of dancefilm to go beyond the dance audience.

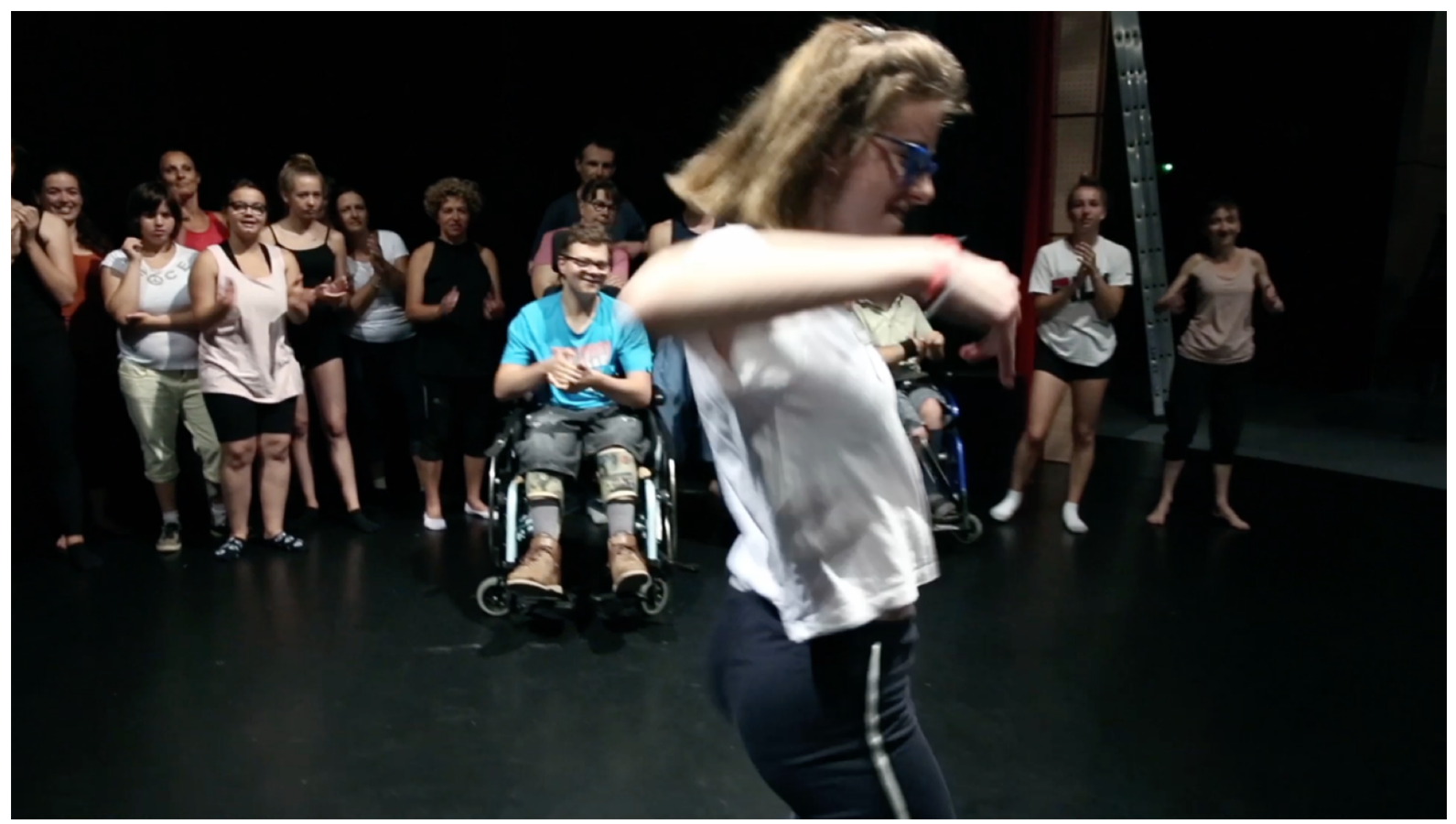

Still from Moving Bodies, 2019.

Hayes and Boulègue from Festival International De Vidéo Danse De Bourgogne: Workshops targeted at not only dancers and filmmakers but also at school children, adults with intellectual disabilities (autism and Down syndrome) and minorities of populations helped to build a local audience in the small city of Le Creusot with an interest in screendance. Inviting the residents to join social practices such as cooking and eating together while also proposing screenings helped to establish further the festival and create an impact on the local community.

\section{Badeka from AVDP (Athens Video Dance Project-International Dance Film Festival).} Screendance is a powerful tool of expression because it can narrate moving stories, bringing the body in the centre of attention and proposing dancefilm as a strong means of communicating current issues. With this in mind, we have organized thematic screenings under the titles: US-and-THE OTHERS (2017), MOVING FORWARD (2018), WOMEN IN ACTION (2019). 
In Greece, the sense of owning a work is stronger because actually the work belongs to many who are the ones that then visit the festival. The audience who attends AVDP is made up of the local artists, their collaborators, their sponsors, their fans, their friends, their family. Therefore, the audience is constituted by the people who are involved in the collaborative process in its broadest sense. This process from the production until its dissemination engages a part of society.

János from CHOREOSCOPE-The International Dance Film Festival of Barcelona: The films that we program are speaking socially and they go beyond the aesthetically 'nice' screendance that features a display of strong dance technique. Subjects that are discussed in our festival include Gender/LGBT+/Inclusion/War/Climate Change/Death/Women \& Feminism.

\section{Question Four}

\section{What can you observe about the evolution of the art form in your country?}

De Rienzo from LA DANZA IN 1 MINUTO CONTEST: As I mentioned in my previous answer, I think that the works that are currently being produced tend to become more socially engaged, to explore social issues and to go beyond the experimentation of the form.

Lisi from CINEMATICA Festival: The technical audio-visual skills, such as editing, shooting and photography, have been improved. However, I see a lack of content in the works of today in comparison to the past when the technical skills were less but the creativity more intense.

Longo from COLLETTIVO AUGENBLICK (Stories We Dance International Videodance Contest): Videodance in Italy receives increasing attention, especially by young people thanks to the accessibility of technologies. It is necessary to encourage a deeper understanding of what a dance film can be and to strengthen research around this art form.

Alexandre from DAN.CIN.LAB.: Artists in the 80s and 90s were audacious and free to experiment with the form. Works used to be funny or aesthetic but with content. When the French TV ceased to support the production of videodance, there was a gap. The arrival of new technologies and the democratisation of technology increased the quantity of screendance productions but not necessarily the content which often is quite poor. Dance films achieving both a fulfilled form and targeting social issues are rare. However, few filmmakers and choreographers gradually begin to build fruitful collaborations.

Hayes and Boulègue from Festival International De Vidéo Danse De Bourgogne. Screendance in France is currently becoming more international and open to 
collaborations from abroad, as French citizens become increasingly open. Also, the colonial past of France is very much present in screendance in the sense that many French filmmakers go to work with African choreographers in former French colonies (Congo, Senegal, Morocco). On one hand, this choice gives visibility to African artists and on the other hand, it follows a colonial model. Furthermore, now that the economy of TV (in terms of financial and technological constraints) is no longer available, artists do not create work in a TV studio and site-specificity has largely become the norm.

Badeka from AVDP (Athens Video Dance Project-International Dance Film Festival). During the 10 years of our festival and regarding the Greek works, storytelling and the medium -- screendance as artform as well as camera work and editing software -- have been mastered and the purely aesthetic -- and almost superficial -- works of the recent past have given way to mature artworks. There are three keywords that describe the Greek screendance landscape: "trust between people, vision and collectivity" which pushes the artists to create thoughtful stories for the screen.

János from CHOREOSCOPE-The International Dance Film Festival of Barcelona: Films, such as Timecode by Juanjo Giménez ${ }^{33}$ or Goya-nominee Bailaora by Rubin Stein have definitely raised interest in dancefilm (rather than screendance). These works highlighted the potential of the form of dancefilm as part of the film industry motivating new productions and collaborations among choreographers and filmmakers. It is like cinema is discovering dance film, a film strand with not so much competition yet that helps young filmmakers to gain visibility easily.

Since Choreoscope started in 2013 we can see a clear increase in screendance productions in Spain. From only a handful a few years ago, in 2019 we received more than 40 projects made in Spain, most of them in Catalonia and the Barcelona area, proving that Choreoscope's efforts to encourage and promote the production of dancefilms is working.

\section{Question Five}

\section{What is the potential of the form to expand the limits of choreography as well as the limits of the screen in relation to new technologies?}

Most of the participants suggest that Virtual and Augmented reality and in general technology-based interactive and immersive performances, when addressed creatively, may represent a positive engagement for the audience that nowadays seeks new experiences. As Alexander concludes "the evolution of new tech as well as maturity coming after experimentation will help to address relevant topics in innovative ways, pushing further their understanding through our body's sensations, emotions and movements". 


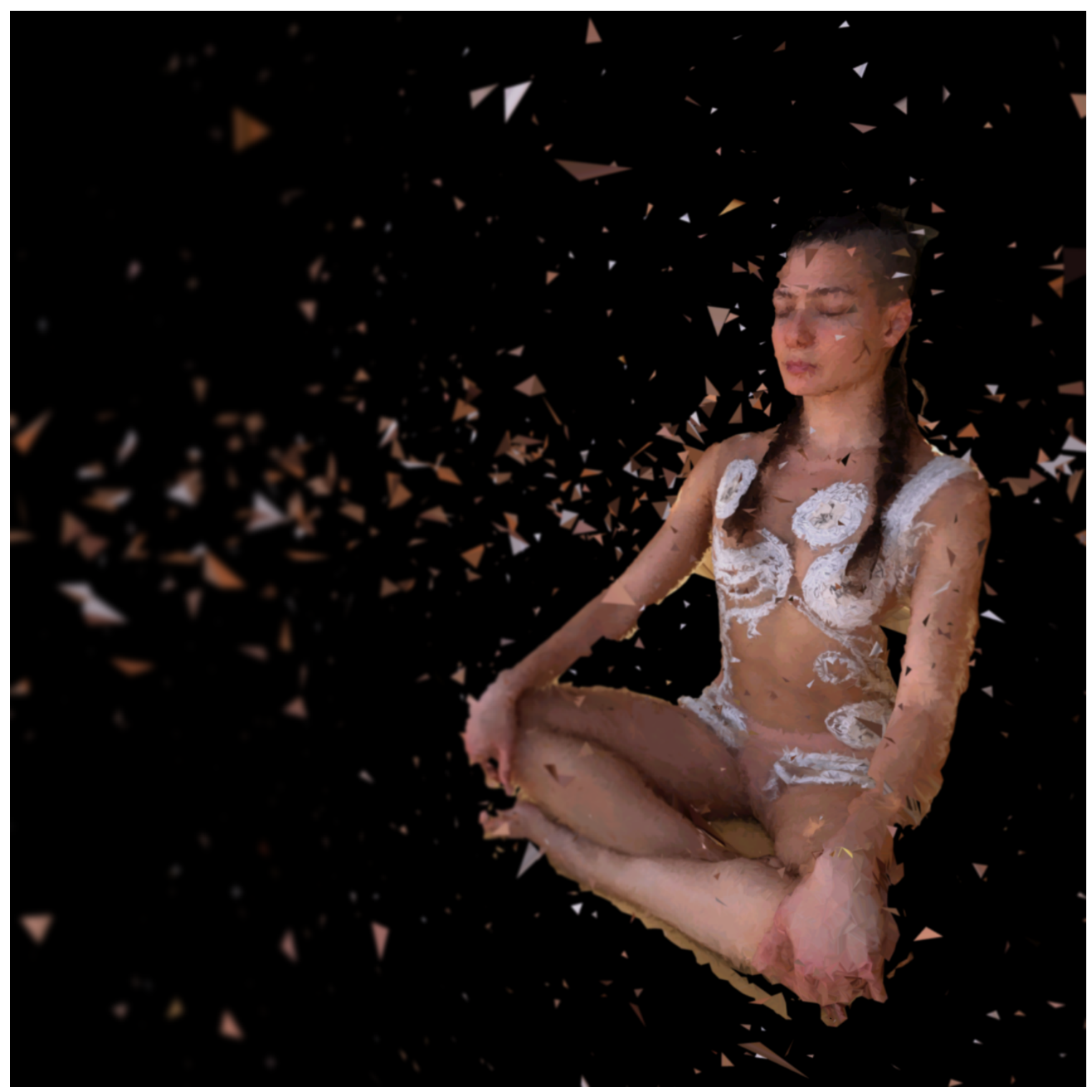

Still from Weightless (work-in-progress) 2019.

\section{Conclusion}

In every country examined in this research different rules apply in relation to screendance production, a result perhaps of different economic landscapes. Education appears to be a common denominator for disseminating the form beyond the context of festivals. Workshops, non-academic lectures, conferences with artists and scholars, thematic programs and the use of social media are common across countries that aim to grow spectatorship locally and at the same time to reach out to a transnational and international audience. Another observation is that screendance becomes more accessible when it leaves its own zone and enters into unexpected contexts or invades the public or digital space, for instance in open-air screenings, community settings, public shootings or private online channels. Additional comments could be 
summarized through the following two points: the stronger the content of the work and perhaps more story-driven, the greater is the potential for social engagement in the discourse developing in the European Mediterranean. Although the use of technology varies from festival to festival - from the low-tech exploration to VR - the mission of technology for all the interviewees is to bring people together.

Most of the participants in this research used the following three words repeatedly, however giving them a different meaning and often referring to a different context:

1. Curation as a responsibility to bring the work of the artist in contact with a wide audience and generate income for them -- as aimed by Choreoscope-The International Dance Film Festival of Barcelona -- and curation as an opportunity for artistic exchange -- as aimed by AVDP (Athens Video Dance ProjectInternational Dance Film Festival).

This kind of responsibility is understood by János as a process of becoming 'commercial' in the same way, as he states, that film directors Alfred Hitchock or David Lynch are commercial and as a result their films have reached a wide audience. He continues by saying that "directing a festival is like having a child" which emphasizes both care and responsibility in his concept of curation. For Badeka, a festival is an opportunity for a social gathering, "a place for meeting, exchange, dialogue and fermentation of ideas" between Greeks and artists from abroad. For both of them, curation is an action of giving back to the artist: in terms of money, visibility or both.

2. Collaboration: Badeka speaks about dancefilm as a collaborative process of collective ownership since a community of friends and family members in Greece is often involved in and supports the production phase of the work. Hayes and Boulègue also speak about collective-authorship between artists in the making of screendance. Through either a collaborative or collective process, screendance is a social practice.

3. Audacious: This refers to the making of the work without knowing how to do it - as for instance the first videodance experiments in France during the $80 \mathrm{~s}$ - and to producing work without having financial means -- such as artists working in Greece during the recent financial crisis.

Regarding the Mediterranean Screendance Network (MSN) which has been formed by the majority of the participants in this research, it holds a geographically and linguistically inclusive name as screendance is "an intentionally broad term that may address any and all work that includes dance andfilm or video as well as other screenbased software/hardware configurations." ${ }^{34}$ Although the network is working towards embracing organisations from the same geographical area with an expanded curatorial 
and aesthetic agenda, at the moment the majority of MSN's members are organisations that focus on cinema and dancefilm.

The debate around the use of the terms 'videodance' and 'dancefilm' is ongoing in the European part of the Mediterranean. As János argues "the lack of a clear definition is still a huge problem in the professional sector" because the terms are not being used with consistency. The supporters of dancefilm look for a linear narrative format in the way that it appears in cinema, which principally emerges from a story -- at least in the way that it is understood among the majority of the interviewees. Alexandre adds to this point by questioning "how do you unite these two ways of writing (choreo-graphy and cinemato-graphy/dance and cinema) to sustain a content?". This question can be answered by approaching screendance as a dancefilm and by looking in the audiovisual form for a specific narrative of the moving body and thus for a specific story that this body can tell beyond the language barriers. Screendance is considered as a medium for non-verbal story-making through a moving body on the screen. Thus, the concepts of recorporealisation ${ }^{35}$ and videodance body ${ }^{36}$ that have been two of the strongest propositions of the videodance origin of screendance are almost out of context here. Furthermore, the way that the motion and the movement beyond the body are read are less relevant as well.

From another point of view, the discussion about the definition of screendance, Boulègue states, removes attention from the work and its right to be undecidable (orig. emphasis), hold an in-between status and still have a strong value. Hayes is inspired by Susan Sontag's quote 'this but also that,' ${ }^{37}$ she adapts it for screendance proposing that "screendance can be this and also that." She supports the potential contribution of screendance to cinema practices and film medium in terms of "how do we read and experience movement, filming techniques, economies, interpretation, analysis [...]. Screendance can impact other fields just as other fields can impact screendance." As Longo suggests through different words, the border becomes a connection and a link 38; the border between disciplines is a place for 'contamination' as well as for sociopolitical intersections.

As curators, artists and researchers we cannot but agree further: the point of meaningful intersection, connection and even 'contamination' of the different origins of screendance is deeply crucial for exploring its full potential. The socio-political area of the European Mediterranean seems to be able to provide rich stimuli towards rendering screendance less a medium of aesthetic exploration but rather a tool that could inspire social change and unite people. Furthermore, as technology tends to replace but also complement human skills and physical contact at all levels of life, the Mediterranean area before the COVID-19 adjustments of social distancing, has proven to be and we hope to remain a strong pole for holding and promoting human values such as collective vision, mutual support, trust and contact between people. Given this particularity, screendance as a tool for communication has a lot of room for growth if practiced towards this direction. 
Acknowledgments: Special thanks to Marisa Zanotti and all the interviewees who have embraced this research from its initial stage until its conclusion.

\section{Author, Collaborator and Contributor Biographies}

Ariadne Mikou (PhD) is a Greek-born artist-researcher currently residing in Italy. With a background as an architect, dance performer and choreographer, her research deals with oral history, alternative modes of archiving, as well as site interventions, processes of transformation and community-making. She is co-founder of futuremellon/NOT YET ART, a collective that enables her to expand her choreographic practice as well as to experiment with the curation of screendance. Her writings have been published in peerreviewed international journals and book anthologies and she is presently collaborating as an Editor with the global theatre portal The Theatre Times. She is currently a Fellow Artist for Creative Europe's Migrating Artists Project_Challenging Dance and Cinema across Europe and a Research Assistant at Memory in Motion. Re-membering Dance Historyat Ca' Foscari University of Venice.

For more info: $\underline{w w w . a m i k o u . c o m}$

Elisa Frasson is a PhD Candidate in Dance Studies at Roehampton University (London). She has been working in different educational and organisational contexts, and for independent and institutional projects, between Italy and the UK. She has extensive experience within organisational contexts of dance and screendance events and with mentoring dance and performance students in creating their own work. Her interests involve dance history, the impact of somatics into choreography, screendance, and electronic music. She has founded and co-curates [SET. me free] Dance \& Movement on Screen, a platform for the promotion of screendance based in Italy. She is currently based in Berlin.

Anna Alexandre is a French artistic director, producer and programmer. She has been working internationally for the last twenty-five years to create new bridges between Dance \& Cinema developing an inclusive creative practice that brings together and at the core of each of her projects artists, amateurs and people with special needs. In 2019, she created with her non-profit organization Stéla a new artistic platform called DAN.CIN.LAB. She signs then her first 52' creative documentary, Moving Bodies, in collaboration with filmmaker Anthony Faye shown both at Berlinale EFM and Art FIFA Montreal, while she launches, with four European partners and the support of Creative Europe, a three-year project titled mAPs (Migrating Artists Project_Challenging Dance and Cinema across Europe) aiming for a collection of four short dance films and one documentary about POWER. In 2020/2021, she will have co-produced no less than 15 dance films -- shorts and documentaries -- and the International Societal Cinema Dance Festival that she runs will celebrate its 10th edition.

Chrysanthi Badeka after her B.A in Dance (Athens), she pursued her M.F.A at Tisch School of the Arts in NYU (New York), focusing on choreography for the camera. Since 
then she has worked as a freelance choreographer, cinematographer, editor and videodance trainer and curator. For 10 consecutive years, she dedicated herself to the promotion of the art of dance film making, co-directing AVDP - International Dance Film Festival (2010-2020) and co-funding The Mediterranean Screendance Network, while now she is the Artistic Director of MØZ Cultural Organisation and Project Manager of mAPs (Migrating Artists Project_Challenging Dance and Cinema across Europe) in Greece (Creative Europe Program). As maker, propelling dance \& composition, her practice merges movement with technology, nature and science working through different mediums, on or off stage to synthetic environments. As an artist she has been supported by the Greek Ministry of Culture, NEON, Onassis Stegi, Compagnia di San Paolo and SIAE (in collaboration with COORPI), State Scholarship Foundation of Greece and NYU. For more info: www.chrysanthibadeka.com

Franck Boulègue is a screendance filmmaker, scholar and educator. He holds a Masters Degree in Screendance Education from La Sorbonne in Paris. He is a regular contributor to film magazines such as LES CAHIERS DU CINÉMA, POSITIF and is the co-editor of the book ART IN MOTION: CURRENT RESEARCH IN SCREENDANCE (2015). As a screendance Lecturer and workshop facilitator, he has taught internationally for The European Video Dance Heritage Project (Maison de la Danse, France \& Universidad Rey Juan Carlos/Museo Reina Sofia, Spain), Hong Kong Academy for the Performing Arts, Hanoi Cinematheque (Vietnam), Université de Bourgogne, and other institutions. The screendance project GAFFE co-created with Marisa C. Hayes won the Susan Braun Award at the New York Dance Films Association. In 2009, he co-founded the Festival International de Vidéo Danse de Bourgogne in France and its conference for the promotion of screendance research. He is currently an associated scholar at the University of Liège in Belgium.

Marisa C. Hayes is an interdisciplinary artist, scholar and curator working at the crossroads of moving images and choreography. In addition to co-directing the Festival International de Vidéo Danse de Bourgogne, she creates screendance films, which have been honoured as "Best Video Dance" by Pentacle Movement Media in New York and the New York Dance on Camera Festival. Her screendance publications include contributions to books and research journals, including THE OXFORD HANDBOOK OF SCREENDANCE STUDIES (Oxford University Press, 2016), CONVERSATIONS ACROSS THE FIELD OF DANCE STUDIES (Society for Dance History Scholars), and THE INTERNATIONAL JOURNAL OF SCREENDANCE. In 2015, she co-edited the book ART IN MOTION: CURRENT RESEARCH IN SCREENDANCE with Franck Boulègue. Following her Master's Degree in Screendance Pedagogy and Transmission at La Sorbonne in Paris, she regularly teaches screendance workshops in France and abroad for universities, choreographic centers, and film/visual art programs. She is editor-in-chief of the French dance research journal REPÈRES, CAHIER DE DANSE and screendance curator at La Briqueterie - National Choreographic Center of Val-de-Marne. She is also the filmmaker for the European project DANCING MUSEUMS. 
Lucia Carolina De Rienzo (Executive Producer COORPI, Torino-IT). After graduating as theatre actress she has worked as dramaturg and assistant director in several stage performances (2007 - 2010). With an MA in Literature at the University of Turin, in 2010 she achieved a Master Degree in Cultural Project Management at Fitzcarraldo Foundation. She has been Project manager of the European project «PerCorpi Visionari» and Performing Arts Consultant at Turin's Metropolitan Urban Center (2014-15). Since 2010 she has worked as project manager and executive producer at COORPI, where she is also Vice President. Artistic director of the screendance contest "La Danza in 1 minuto" and of "Campo Largo", the first Italian artistic residency focused on screendance. She is Executive Producer of transmedia dance projects: "re - FLOW" and "Zona Martiska". In the last 5 years she produced with COORPI 25 original short dance films, which have been selected in international festivals in over 40 different countries and won 13 different awards.

Loránd János is the Artistic Director of Choreoscope - International Dance Film Festival of Barcelona and co-artistic Director of Moovy Tanzfilmfestival Köln. His films have been selected by festivals such as Dance on Camera, Jumping Frames, Videodance Buenos Aires, Dança em Foco, MashRome, Boomtown Film \& Music Festival, Tanzbiennale Heidelberg. In 2015, a retrospective of his work was screened at the III Video and Experimental Art exhibition Vartex Medellín, Colombia. In 2014 he was a member of the jury of the Production Grant Review Panel for the Dance Films Association New York in the selection of post-production grants for screendance projects. He participated in the International Meeting of Performative Research of the University of the Basque Country, the VI International Dance Congress of the University of Malaga, the Future Screens of Dance Conference of the Loikka International Dance Film Festival in Helsinki and the History and Theory of the Dance Seminar of the Complutense University of Madrid.

Simona Lisi. Dancer, actress, choreographer, independent dance aesthetics researcher. BA in Philosophy , PG Degree in Contemporary Dance at London LCDS, BMC ${ }^{\circledR}$ Somatic Movement Educator. Dance/theatre artist as well as performance and videodance maker, she is the artistic director of Cinematica festival that hosts the Corporeality and New Media National Conference in partnership with the Italian Philosophical Society and the Polytechnic University of Marche. Cinematica Festival has run the International Cinematica Videodance Competition since 2015 and co-produced the dance film Scalamare by Jiří Kylián. Lisi's philosophical research deals with dance as a language and body as generator and meaning translator and her written contributions are present in Looking for dance by Various Authors (Costa \& Nolan 2000), Light, body space (Artdigiland 2013), Creators of Meaning (Aracne), Agalma nr 35 (Mimesis Edizioni).

For more info: www.simonalisi.it \& www.cinematicafestival.com

Graduated in Film Directing (Civica Scuola di Cinema Luchino Visconti, Milan) with a background in Literature (Università degli Studi, Pavia), Marco Longo is a filmmaker, independent producer and teacher. Co-founder - with Alessandra Elettra Badoino, theatrical set designer, performer and Danzeducatore ${ }^{\circledR}$; Marina Giardina, dancer and 
performer and Fabio Poggi, PhD in Urbanism and performer - of Augenblick Associazione Culturale, a video dance collective based in Genoa. Augenblick curates Stories We Dance, the video dance section of FuoriFormato Festival, in Genoa.

\section{References}

Aporia, Direction and choreography Salvatore Insana and Elisa Turco Liveri, co-funded by Festival International De Vidéo Danse De Bourgogne. 2019. Screendance.

Art for Social Change Video. Organized by Agora for Arts and Culture, The Arab Origami Center, El Madina for Performing and Digital arts and the Spanish Embassy of Egypt. Prod. Figleaf. 2011. Video documentary.

Augenblick Collettivo. Accessed 11 Apr. 2020. https://augenblick.it/about

Athens Video Dance Project - International Dance Film Festival. Accessed 11 Apr. 2020.

http://www.avdp.gr

Bailaora. Dir. Rubin Stein. Prod. Nirvein. 2018/2019. Film.

Cambridge Dictionary online. Accessed 9 Apr. 2020.

https://dictionary.cambridge.org/dictionary/english/contaminate

Campo Largo, 10 original short films. Prod. COORPI; Casa*Marziano-Experimental Film Virginia. Accessed 25 May 2020. https://vimeo.com/showcase/4278681

Choreoscope - The International Dance Film Festival of Barcelona. Accessed 11 Apr. 2020.

http://www.choreoscope.com

Cinematica Festival - Immagine in Movimento: Performance, Arti Visive, Cinema, Nuove Tecnologie. Accessed 11 Apr. 2020. http://www.cinematicafestival.com/

COORPI/La Danza in 1 minuto. Accessed 11 Apr. 2020. https://coorpi.org/portfolio/progetto-la-danza-in1-minuto/

DAN. CIN. LAB.. Accessed 11 Apr. 2020. http://www.dancinlab.co

Deleuze, Gilles (1983). The Movement-Image. Trans. Barbara Habberjam. London: Bloomsbury, 2013.

Dodds, Sherril. Dance on Screen: Genres and Media from Hollywood to Experimental Art. Basingstoke: Palgrave Macmillan, 2004. https://doi.org/10.1057/9780230509580

Festival International De Vidéo Danse De Bourgogne. Accessed 11 Apr. 2020.

https://videodansebourgogne.com/

Filmin. Accessed 9 Apr. 2020. https://www.filmin.es/

Filmin Choreoscope short film catalogue. Accessed only between 31 Oct. and 31 Dec. https://www.filmin.es/canal/choreoscope

Fondo Unico Per Lo Spettacolo (FUS). Accessed 11 Apr. 2020.

http://www.spettacolodalvivo.beniculturali.it/index.php/contributi-online 
Fuori Formato - Festival Internazionale di Danza e Video Danza. Accessed 11 Apr. 2020. https://www.fuoriformatofestival.it/

Kylián, Jiří. Scalamare, 2014. Dir. and chor. Jiří Kylián. Prod. Kylian Foundation, Cinematica Festival, Comune di Ancona, Marche Teatro. Film.

La Collection: Comédie musicale: Plot, Dir. Sébastien Auger; Quatorze ans, Dir. Barbara Carlotti; Monsieur, Dir.Thomas Ducastel; Belle étoile, Dir. Valérie Leroy; Rap-night, Dir. Salvatore Lista; BBQ, Dir. Jeanne Mayer; Fin de saison, Dir. Matthieu Vignau. Prod. CNC, Canal+. 2020.

mAPs (migrating Artists Projects). Accessed 11 Apr. 2020. http://migratingartists.com/

Mediterranean Screendance Network, The. Accessed 10 Apr. 2020. http://screendancenetwork.com/

Moving Bodies, 2019 supported by CNC - French National Film Fund and French Ministry of Culture. Dir. Anna Alexandre and Anthony Faye. Prod. DAN.CIN.LAB, Nomade Productions Films, TL7 - Télévision Loire 7, YN Productions. Documentary.

Open Borders. Dir. Marisa C. Hayes, Franck Boulègue. Prod. Festival International De Vidéo Danse De Bourgogne. 2015. Accessed 13 Apr. 2020. https://www.numeridanse.tv/en/dance-videotheque/openborders

Per Chi Crea. Accessed 11 Apr. 2020. https://www.perchicrea.it/

Rosenberg, Douglas. Screendance: Inscribing the Ephemeral Image. New York; Oxford: Oxford University Press, 2012. https://doi.org/10.1093/acprof:oso/9780199772612.001.0001

Sampson, Cherie. "Body Cinema's Sacre/ilège(s) - Re-interpretations of a modernist classic in contemporary screendance." Screendance Studies. Art in Motion. Accessed 13 Apr. 2020. https://screendancestudies.wordpress.com/2014/04/25/body-cinemas-sacreileges-re-interpretationsof-a-modernist-classic-in-contemporary-screendance-2/

Scalamare, 2014. Dir. and chor. Jiř́ Kylián. Prod. Kylian Foundation, Cinematica Festival, Comune di Ancona, Marche Teatro. Film.

[SET.mefree] Dance \& Movement on Screen. Accessed 12 Apr. 2020.

https://setmefreecall.wixsite.com/events

SIAE. Accessed 11 Apr. 2020. https://www.siae.it/en/about-us/siae/siae-s-mission

Susan Sontag, Interviewed by Edward Hirsch. Accessed 26 May 2020. Available at: http://franciscovazbrasil.blogspot.com/2012/05/susan-sontag-interviewed-by-edward.html

TATE online. Accessed 9 Apr. 2020. https://www.tate.org.uk/art/art-terms/c/cadavre-exquis-exquisitecorpse

Timecode. Dir. Juanjo Giménez and chor. Lali Ayguadé. Prod. Nadir Films SL. 2016. Film.

Weightless (work-in-progress) 2019. Digital Artist Andrej Boleslavský and chor. Chrysanthi Badeka. Virtual Reality project. 


\section{Notes}

${ }^{1}$ In April 2018, we curated Screendance Landscapes, a two-day symposium designed to explore different strands of screendance both as theory and practice. Building on this event, in January 2020 we designed and delivered the screendance workshop SOMA.CI(ty)NEMA that aimed to put into an interdisciplinary dialogue the moving body and the moving image with the urban context of the city of Venice. Both the symposium and the workshop were hosted by the Theatre and Performing Arts Master Program at IUAV University of Venice. An archive of our curatorial work can be found on the website of [SET.mefree] Dance \& Movement on Screen.

${ }^{2}$ At the Screendance Landscapes event we launched a call on the theme of POSITIONING. For this call, we were interested in gathering screendance works that take advantage of the "transportability of the camera and the body in sites of conflict or areas that need attention" (from the Selected Submissions document found on the site of [SET.mefree] Dance \& Movement on Screen).

${ }^{3}$ The interviews were in total seven. They lasted from 60 to 120 minutes and they took place one to one.

${ }^{4}$ Badeka was the co-Artistic Director of AVDP until January 2020 when she left the project in order to continue her career as an independent artist, videodance educator and curator and to focus on her role as Project Manager in Greece for mAPs-migrating Artists Project.

${ }^{5}$ The members of the Mediterranean Screendance Network at the time of writing are DAN.CIN.LAB. , Athens Video Dance Project - International Dance Film Festival, Choreoscope - The International Dance Film Festival of Barcelona, Festival de Videodanza de Palma, COORDINAMENTO DANZA PIEMONTE (COORPI) and collettivo Augenblick.

${ }^{6} \mathrm{mAPs}$ (migrating Artists Projects) is one of the first European funding from Creative Europe dedicated to the production of four short dance films that focus on social issues and one documentary of the creative process of the overall project. This funding opportunity is available only for artists with citizenship from Finland, France, Greece \& Italy. The mAPs project was created by STÉLA DAN.CIN.LAB/France; COORPI/Italy; MALAKTA FILMS/Finland; TANZRAUSCHEN e.V./Germany; Chrysanthi BADEKA/Greece. According to Anne Alexandre from DAN.CIN.LAB., mAPs is committed to engaging communities through the artists' creative processes.

${ }^{7}$ Shortly before the publication of this article, Ariadne Mikou, the main author of this article, has been selected as a choreographer to participate together with filmmaker and audiovisual anthropologist Konstantina Bousmpoura to Creative Europe funded project mAPs.

${ }^{8}$ [SET.mefree] Dance \& Movement on Screen / about

${ }^{9}$ Lucia De Rienzo, the vice president of COORPI emphasises the cinematic approach on behalf of COORPI by declaring that "the duration of works we select, program and produce are aimed to be strongly cinema driven (orig. emphasis). They are films." The director of Chorescople - The International Dance Film Festival of Barcelona also makes explicit: "Choreoscope is NOT (orig. emphasis) a screendance festival, it is a dance film festival. We rarely program videodance or other audiovisual translations of dance on screen."

${ }^{10}$ The MEDIA sub-program of Creative Europe funding is open to all members of the European Union. It is possible to apply as a production company for film and audio-visual support.

${ }^{11}$ Videodance is known as 'videodanza' in Italian and 'videodanse' in French. 
${ }^{12}$ The call PER CHI CREA was known as SILLUMINA until 2019.

${ }^{13}$ SIAE is the Italian Society of Authors and Publishers.

${ }^{14}$ For instance, Fondazione Cariplo :: progetto La città Intorno; Fondazione Compagnia di San Paolo-Ora! and Fondazione CRT in Torino.

${ }^{15}$ Campo Largo (2016) is the first residency opportunity in Italy dedicated to videodance and it has been promoted by COORDINAMENTO DANZA PIEMONTE (COORPI).

${ }^{16}$ Carte Blanche (2017) was produced in cooperation with Université Nice Sophia Antipolis and Université Sorbonne Nouvelle - Paris 3 in France and Università degli Studi di Genova in Italy.

${ }^{17}$ As Hayes specifies, in 2019 "12 projects received from 5.000 to 20.000 euros."

${ }^{18}$ The winners of the 1st International Call were the Italian artists Salvatore Insana and Elisa Turco Liveri who produced the short film Aporia (2019).

${ }^{19}$ The Anna Lindh Foundation has funded Montenegro Film Festival, International Music + Media Centre (IMZ), the documentary Art for Social Change.

${ }^{20}$ The project Dancing Cities, directed by Thibaut Ras and co-produced by ALL WE CAN DO IS DANCE, has been supported by the French Institute of Budapest.

${ }^{21}$ During the years of the financial crisis in Greece, the festival received the annual amount of 3.000 euros from the J.F. Kostopoulos Foundation (3rd, 4th, 7th, 8th and 9th edition), a state grant equal to 5.000 euros by the Greek Ministry of Culture (separately for the 9th and 10th edition) and since its 4th edition the Greek Radio \& TV (EPT) recognized AVDP as the International Dance Film Festival of Greece and it became one of the main sponsors of communication.

22 Prêt a porter, directed by Panos Boudouroglou and choreographed by Xanthippi Papadopoulou in 2014, won the International Prize-La Danza in 1 minuto in the 2017 edition. SinkUp by Christos Xyrafakis and Antonis D. Tzoumas won the Audience Award in 60secondsdance (Finland) in 2017. Coated directed by Antigone Davaki and choreographed and performed by Vassia Zorbali and Evi Psaltou was the winner in 60secondsdance (Finland) in 2017.

${ }^{23}$ Vassilis Arvanitakis is a Greek artist who shows a particular sensibility to social issues. Remains (2018), his artistic response to the Greek financial crisis, has a symbolic character and it won several awards such as the 1st Prize - 60seconds Denmark 2018 and the 1st Prize - Ork Kota Plattform 2019 in Hungary.

${ }^{24}$ In 2013, during the first edition of our festival, we introduced the work of Maya Deren through a program under the title Lo sguardo che circonda and the following year we included Random Acts - $A$ British Council Touring Programme. The work of Billy Cowie and especially his 3D videos were very well received by our audience which initially originated from the local dance scene.

${ }^{25}$ Kylián, Scalamare

${ }^{26}$ A note on translation from Italian to English: in this context and since our interviewee is Italian, we borrow the definition of the verb 'contaminate' and its derivative noun 'contamination' as it appears in Italian. Therefore, 'contamination', which according to Cambridge Dictionary online in English means "to make something less pure or make it poisonous," is intentionally misappropriated in order to define the fusion of artistic elements. Therefore, by 'contaminating' screendance, the intention is to speak about the entrance of screendance into an interdisciplinary discourse. 
${ }^{27}$ As for instance, the Museum of Mine in Saint-Etienne.

${ }^{28}$ Le Creusot is currently in extreme economic decline. In the past and prior to the 50 s, it used to be an important industrial capital of France. Currently, it is home to a large elderly population.

${ }^{29}$ Exquisite Corpse is "similar to the old parlour game consequences - in which players write in turn on a sheet of paper, fold to conceal what they have written, and pass it on to the next player - but adapted so that parts of the body are drawn instead" (TATE online). As Hayes and Boulègue explain, an "exquisite corps technique" is enabled by the communication between artists through internet technology and the possibility to transfer digital files. In this technique, every participating artist is working remotely in his/her country of residency. For the final collated outcome, the screen becomes a shared co-authored space and different visions of the same theme can emerge. Examples include: Sacre/ilège(s) -- in tribute to the Rite of Spring centenary in 2013 -- and Open Borders in 2015 - a collective film in support of migrants, a message from European-based artists to their governments regarding immigration and asylum policies.

${ }^{30}$ At a national level, AVDP collaborates with Akropoditi Dance Festival in Syros, Dance Days Chania Festival in Crete and Dimitria Festival in Thessaloniki.

${ }^{31}$ The Filmin platform is equivalent to Netflix but is available only for Spanish and Spanish-speaking countries.

${ }^{32}$ In Italian, it appears as "Cosa ti muove?"

${ }^{33}$ Interestingly, Juanjo Giménez is a film director who does not consider his work a dancefilm although dance has a central place in his film Timecode. He won the Palme d'Or 2016 for the Best Short Film in the Festival de Cannes.

${ }^{34}$ Rosenberg, 3

${ }^{35}$ Ibid., 55. Recorporealization is "the literal re-construction of the dancing body via screen techniques; at times a construction of an impossible body."

36 " $\mathrm{t}$ ] $\mathrm{he}$ televisual mediation of dance creates a 'video dance body' that transcends the limitation of the material body which offers the possibility of alternative modes of dance [...] the spatiotemporal boundaries of the body can be made to appear increasingly fluid, dynamics can be manipulated independently of the physical body" (Dodd 2004:170).

${ }^{37}$ Full quote: "It isn't that I like it and I don't like it—-that's too simple. Or, if you will, it isn't 'both yes and no.' It's 'this but also that.' I'd love to settle in on a strong feeling or reaction. But, having seen whatever I see, my mind keeps on going and I see something else. It's that I quickly see the limitations of whatever I say or whatever judgment I make about anything. There's a wonderful remark of Henry James: 'Nothing is my last word on anything.' There's always more to be said, more to be felt." (Susan Sontag, Interviewed by Edward Hirsch).

${ }^{38}$ In Italian, it appears as "il confine diventa un legame." 